\title{
Analisis Proses Formulasi Peraturan Daerah \\ (Studi Pada Peran DPRD Lombok Barat Dalam Proses Formulasi Perda No 3 Tahun 2015 Tentang Pedoman Umum Pelaksanaan Pengarusutamaan Gender Dalam Pembangunan Di Kabupaten Lombok Barat)
}

\author{
Mustamin H. Idris ${ }^{1}$, Rahmad Hidayat ${ }^{2}$, Mahsar $^{3}$ \\ 1Prodi Administrasi Publik, Universitas Muhammadiyah Mataram, Indonesia \\ 2Prodi Administrasi Publik, Universitas Muhammadiyah Mataram, Indonesia \\ ${ }^{3}$ Prodi Administrasi Publik, Universitas Muhammadiyah Mataram, Indonesia
}

\section{INFO ARTIKEL}

\section{Riwayat Artikel:}

Diterima: 05-02-2018

Disetujui: 01-03-2018

\section{Kata Kunci:}

1. Formulasi

2. Kebijakan

3. PERDA

4. Lombok Barat

\begin{abstract}
ABSTRAK
Abstrak: Reformasi dan otonomi daerah telah berjalan di Negara ini dan diharapkan mampu memberikan kehidupan yang lebih demokratis. Salah satunya tuntutan terhadap Dewan Perwakilan Rakyat Daerah (DPRD) untuk menjalankan tugas dan fungsinya di daerah, salahnya fungsi legislasi, proses formulasi PERDA (Peraturan Daerah). Tujuan penelitian ini dimaksudkan untuk mengkaji penyelenggaraan peran DPRD Kabupaten Lombok Barat sebagai salah satu aktor Formulasi Kebijakan PERDA No. 3 Tahun 2015 Tentang Pedoman Umum Pelaksanaan Pengarusutamaan Gender Dalam Pembangunan Di Kabupaten Lombok Barat dan Faktor yang mempengaruhinya.
\end{abstract}

Metode yang digunakan dalam penelitian ini yaitu metode kualitatif dengan pendekatan deskriptif, data dalam penelitian ini berupa data primer dan sekunder dalam bentuk observasi, wawancara dan dokumentasi.

Hasil penelitian menunjukkan bahwa peran DPRD Kabupaten Lombok Barat sebagai salah satu aktor Formulasi Kebijakan PERDA ini sudah dilihat dari perannya dalam penyusunan Rancangan Peraturan Daerah, dimana sebagian besar sudah dijalankan sesuai dengan Standar Operasional Prosedur (SOP), yaitu mengikuti prosedur penyusunan Raperda dan penyiapan Raperda. Aktor lain yang juga terlibat yaitu Badan Keluarga Berencana dan Pemberdayaan Perempuan (BKBPP). Faktor Pendukung yaitu dalam bentuk anggaran sebagai bentuk dukungan dari anggaran APBD untuk bidang pemberdayaan perempuan, sarana dan prasarana pembentukan Raperda Inisiatif DPRD. Sedangkan faktor penghambat dalam pembentukan Raperda Inisiatif ini Sumber Daya Manusia (SDM) Tenaga ahli tetap yang belum tersedia dalam pembentukan Raperda tentang Pengarusutamaan Gender.

\section{Abstrack}

Reform and regional autonomy are under way in the country and are expected to provide a more democratic life. One of them is the demands of the Regional People's Legislative Assembly (DPRD) to carry out its duties and functions in the regions, the wrong function of legislation, the formulation process of Regional Regulation (PERDA). The purpose of this study is intended to examine the role of the West Lombok Regional House of Representatives as one of the actors of Policy Formulation of PERDA. 3 of 2015 on General Guidelines of Gender Mainstreaming in Development in West Lombok Regency and the Factors Affecting it.

The method used in this research is qualitative method with descriptive approach, the data in this research are primary and secondary 
Keyword:

1. Formulation

2. Policy

3. Regional Regulation

4. West Lombok data in the form of observation, interview and documentation.

The results of this research indicate that the role of West Lombok Regency DPRD as one of the actors of PERDA Formulation is seen from its role in the drafting of Local Regulation, where most have been run in accordance with Standard Operating Procedures (SOP), following the procedure of drafting of Raperda and preparing Raperda. Other actors involved are Family Planning and Women Empowerment (BKBPP). Supporting Factors are in the form of budget as a form of support from the budget of APBD for the field of women's empowerment, facilities and infrastructure formation Raperda Initiative DPRD. While the inhibiting factor in the formation of Raperda Initiative is Human Resources (HR) Experts remain that are not yet available in the formulation of Raperda on Gender Mainstreaming.

\section{Latar Belakang}

Reformasi dan otonomi daerah telah berjalan di Negara ini dan diharapkan mampu memberikan kehidupan yang lebih baik bagi masyarakat di berbagai sektor kehidupan. Adanya ekonomi dan desentralisasi kekuasaan dari pusat kepada daerah untuk mengelola maupun mengantur pemerintahan didaerahnya masing-masing, yang berbarengan dengan kemampuan masyarakat lokal untuk dapat berperan aktif dalam pengelolaan daerahnya tersebut. Peran serta masyarakat setempat sangat berpengaruh sekali terhadap laju perkembangan daerah dan juga jalannya pemerintahan di tersebut.

Dalam UU No. 32 tahun 2004 tentang Pemerintahan Daerah, landasan hukum untuk menggulirkan pemerintah lokal yang otonom dan demokratis sangatlah terbuka. Dewan Perwakilan Rakyat Daerah (DPRD) merupakan salah satu pilar untuk melaksanakan demokrasi berdasarkan tersebut, yang tentunya berdasarkan Pancasila. Namun sebelumnya, peran maupun fungsi eksekutif lah yang cukup dominan bahkan fungsi legislatif pun diperankan oleh eksekutif. Seperti ditegaskan oleh Miriam Budiajo: "telah menjadi gejala umum bahwa titik berat dibidang legislatif telah bergeser ketangan eksekutif (Budiarjo, 1994: 299)

DPRD adalah salah satu lembaga yang mewakili seluruh lapisan masyarakat dalam pemerintahan. Namun dalam realitanya selama ini, lembaga perwakilan tersebut menjalankan peran dan fungsi sebagai wakil rakyat belum bisa memberikan sumbangsih yang begitu maksimal terhadap kepentingan masyarakat. Hal ini dapat lihat, dimana seringnya kebijakan-kebijakan yang telah ditetapkan/di putuskan oleh pemerintah sama sekali tidak memihak tehadap kepentingan masyarakat ataupun tidak sesuai dengan aspirasi masyarakat.
Di era sekarang sekarang, adanya tuntutan kepada menguatnya peran DPRD saat ini, yang mana peran DPRD sebagai posisi sentral yang biasanya tercermin dalam doktrin kedaulatan rakyat di era otonomi daerah ini, merupakan fenomena yang cukup menarik. Tanggapan-tanggapan pesimis yang sebelumnya mengarah kepada institusi lembaga perwakilan ini kini menjadi pembahasan yang cukup menarik. Pergeseran akan peran dan fungsi lembaga legislatif di era otonomi daerah ini di tandai dengan penegasan akan peran tugas dan wewenang DPRD, yakni selain menyerap dan menyalurkan aspirasi masyarakat menjadi sebuah kebijakan pemerintah daerah juga melakukan fungsi pengawasan. Lebih tegas lagi dinyatakan dalam penjelasan umum UU No 32 Tahun 2004, bahwa DPRD harus menyatu dengan masyarakat daerah dan dipisahkan dari pemerintah daerah.

Sampai beberapa waktu yang lalu, hak untuk berpartisipasi masyarakat dalam pembuatan keputusan, untuk memberikan suara atau untuk menduduki suatu jabatan pemerintah telah dibatasi hanya untuk sekelompok kecil orang yang berkuasa, kaya dan keturunan terpandang. Salah satu tuntutan yang sering disuarakan di era reformasi dan otonomi daerah sampai sekarang ini adalah peran serta atau partisipasi masyarakat secara aktif dan nyata dalam menentukan kebijakan yang menyangkut hajat hidup masyarakat itu sendiri. Namun pastisipasi itu sendiri sering tidak mendapatkan makna dan arti sebenarnya. Seperti yang diungkapkan oleh Kumorotomo (1996:112) sebagai berikut: "realita politik menunjukkan, bahwa umumnya pejabat politik sudah merasa melaksanakan kewajibannya untuk merangsang partisipasi masyarakat jika para warga negara sudah mengikuti pemungutan suara dengan tertib, ikut menghadiri rapat umum, atau bersikap harmonis 
terhadap program-program atau kebijakan yang direncanakan".

Keberadan lembaga perwakilan rakyat mengandung maksud bahwa rakyat diharapkan ikut berperan dalam penyelenggraraan pemerintahan daerah melalui para wakilnya yang berada di DPRD, lebih lanjut Awang (1991) mengemukakan sebagai berikut: "kedalam berperannya anggota DPRD untuk menyalurkan aspirasi menyarakat pada hakikat berkenan dengan masalah hubungan antara badan tersebut dengan anggota masyarakat yang diwakili mereka secara individu, berdasarkan kelompok maupun secara keseluruhan, sehingga secara principal setiap wakil wakil haruslah melihat dirinya sebagai mewakili warga negara yang berada di dalam batas ruang lingkup perwakilan secara keseluruhan".

Dengan demikian kedudukan serta keberadaan lembaga perwakilan rakyat mengundang arti penting dalam memperhatikan kepentingan rakyat yang dirumuskan dalam suatu kebijakan pemerintah sehingga diharapkan timbulnya keterpaduan antara kebijakan yang dirumuskan dengan partisipasi masyarakat secara aktif, nayat dan bertangungjawab. seperti yang dirumuskan dalam UU No. 32 Tahun 2004, dengan kata lain bahwa DPRD merupakan lembaga yang berperan sekaligus berfungsi sebagai agen perubahan sosial.

Salah satu perhatian lembaga legislatif adalah pengarusutamaan gender yang terjadi di lapangan. Sehingga Presiden dan lembaga legislatif merumuskan kebijakan PUG untuk memberi kesetaraan gender dan hak-hak masyarakat khususnya perempuan dalam tatanan masyarakan maupun di lembaga-lembaga pemerintahan dalam pembangunan. Untuk itu pemerintah Indonesia menyarankan pemerintah Provinsi, Kabupaten/kota untuk menjadikan PUG sebagai strategi pembangunan.

Pengarusutamaan Gender (PUG) pertamakali muncul saat Konferensi PBB untuk Perempuan ke IV di Beijing tahun 1995. Pada saat itu, berbagai area kritis yang perlu menjadi perhatian pemerintah dan masyarakat di seluruh dunia untuk mewujudkan kesetaraan gender mulai dipetakan. PUG didesakkan sebagai strategi yang harus diadopsi oleh $\mathrm{PBB}$, pemerintah, dan organisasi yang relevan untuk memastikan bahwa rencana aksi di berbagai area kritis dapat dilaksanakan dengan efektif. Pengarusutamaan gender merupakan sebuah strategi, bukan tujuan. Strategi ini dirumuskan agar desain, implementasi, monitoring, dan evaluasi kebijakan dan program di seluruh ranah politik, ekonomi, sosial, dan budaya dapat terwujud. Sedangkan tujuan utamanya adalah mewujudkan keadilan gender. Dengan PUG maka semua program pembangunan dapat dilaksanakan dengan mempertimbangkan kesempatan dan akses perempuan terhadap program pembangunan, serta dengan adanya kendali dan manfaat untuk perempuan.

Di Indonesia, secara resmi PUG diadopsi menjadi strategi pembangunan bidang pemberdayaan perempuan melalui Instruksi Presiden (Inpres) Nomor 9 Tahun 2000 tentang Pengarusutamaan Gender dalam Pembangunan Nasional. Dalam inpres tersebut dinyatakan tujuan PUG adalah terselenggaranya perencanaan, penyusunan, pelaksanaan, pemantauan, dan evaluasi atas kebijakan dan program pembangunan nasional yang berperspektif gender. Dan strategi PUG ditempuh dalam rangka mewujudkan kesetaraan dan keadilan gender dalam kehidupan berkeluarga, bermasyarakat, berbangsa, dan bernegara. Dalam rangka mengintegrasikan pengaurusutamaan gender dalam proses perencanaan dan penganggaran, pada tahun 2003 diterbitkan Keputusan Menteri Dalam Negeri Nomor 132 tahun 2003 tentang Pedoman Umum Pelaksanaan Pengarusutamaan Gender Dalam Pembangunan di Daerah. Pada tahun 2008 dikeluarkan Peraturan Menteri Dalam Negeri Nomor 15 Tahun 2008 tentang Pedoman Pelaksanaan Pengarusutamaan Gender di Daerah dan telah diperbaharui dengan Peraturan Menteri Dalam Negeri Nomot 67 Tahun 2011. Peraturan ini menginstruksikan pada semua unit pemerintah di bawah koordinasi Badan Perencanaan Pembangunan Daerah (Bappeda), untuk mengintegrasikan pengarusutamaan gender ke dalam perencanaan dan penganggaran. Menurut Permendagri tersebut, penyusunan kebijakan, program, dan kegiatan pembangunan berperspektif gender dituangkan dalam Rencana Pembangunan Jangka Menengah Daerah atau RPJMD, Rencana Strategis SKPD, dan Rencana Kerja SKPD.

Dalam rangka pelaksanaan pengarusutamaan gender dalam perencanaan dan penganggaran di daerah, Permendagri Nomor 15 tahun 2008 yang diperbaharui dengan Permendagri Nomor 67 Tahun 2011 juga mengamanatkan kepada kabupaten/kota untuk menyusun Rencana Aksi Daerah Pengarustamaan Gender (RAD PUG). Untuk mengimplementasikan amanat tersebut.

Rencana Aksi Daerah Pengarusutamaan Gender (RAD PUG) berisi apa yang harus dilakukan oleh siapa dengan cara bagaimana, dan output/outcomenya apa sehingga strategi pengarusutamaan gender benar-benar dapat 
diimplementasikan dalam rangka mewujudkan Kesetaraan dan Keadilan Gender (KKG).

Tujuan Penyusunan Rencana Aksi Daerah Pengarusutamaan Gender adalah sebagai berikut:

1. Memberikan panduan dan arahan di dalam menyusun kebijakan, program dan kegiatan dari tahap perencanaan, pelaksanaan dan monitoring evaluasi (monev) yang responsif gender pada setiap tahapan pembangunan.

2. Mengefektifkan pelaksanaan strategi PUG secara lebih konkrit dan terarah untuk menjamin agar perempuan dan laki-laki memperoleh akses, partisipasi, mempunyai kontrol dan memperoleh manfaat yang adil dari pembangunan, dan berkontribusi pada terwujudnya keadilan dan kesetaraan gender.

Rencana Aksi Daerah Pengarusutamaan Gender ditujukan untuk percepatan pencapaian millenium Development Goals (MDG), yaitu Menanggulangi Kemiskinan dan Kelaparan, Mewujudkan Pendidikan Dasar Untuk Semua, Mendorong Kesetaraan Gender dan Pemberdayaan Perempuan, Menurunkan Angka Kematian Anak, Meningkatkan Kesehatan Ibu, Memerangi HIV AIDS, Malaria dan penyakit menular lainnya dan Pelestarian Lingkungan, sesuai isu strategis di setiap tujuan. Sehingga pemerintah Indonesia mengadopsi PUG untuk memecahakan kesetaraan gender diberbagai wilayah.

Jika dihubungkan dengan pengaruhnya terhadap bidang kesehatan dimana usia mudah lebih banyak wanitanya, dan ternyata banyak diantara mereka yang telah menika dini, maka menjadi perhatian khusus bagi pemerintah. Maka Ketimpangan masalah gender juga turut menjadi salah satu penyebab kematian ibu, di mana banyak di antara ibu-ibu meski sedang hamil tetap bekerja seperti biasa, padahal normalnya harus mengurangi beban kerja dan perbanyak istirahat, namun dalam kenyataannya seringkali terlalu banyak bekerja.

Menurut laporan maternal dinas kesehatan Kabupaten Lombok Barat kasus kematian ibu 3 tahun terakhir mengalami penurunan pada tahun 2013 tercatat jumlah kematian ibu sebanyak 10 orang dan tahun 2014 menurun menjadi 7 kasus , terakhir tahun 2015 jumlah kasus menurun menjadi 5 kasus. Faktor penyebab kematian adalah adalah hipertensi dalam kehamilan terutama pre ekalmpsia dan eklampsia, pendarahan dan emboli. Upaya yang dilakukan untuk menekan kematian ibu yakni dengan meningkatkan kualitas pelayanan kai di pelayanan kesehatan dasar melalui programprogram diantaranya pelayanan kesehatan, meningkatkan kegiatan supervisi fasilitatif, penguatan manajemen program kia di tingkat bidan desa, peningkatan kompetensi bidan dalam penanganan kasus berupa pelatihan-pelatihan.

Jumlah kematian bayi di Kabupaten Lombok Barat menurun secara segnifikan. Tahun 2014 menurun sebesar 30\% pada tahun 2015 dengan perincian penyebab kematian bayi paling besar adalah berat bayi lahir rendah (BBLR) yaitu sebanyak 12 (menurun dari tahun sebelumnya 51 kasus). untuk kematian ibu dapat di katakan fluktuatif, terjadi penurunan pada tahun 2012 dan 2015. Tahun 2015 terbanyak ibu mati saat bersalin (5 orang) dan semuanya pada kelompok usia 20-34 tahun. sedangkan untuk tahun 2015 ini penyebab kematian ibu paling tinggi tahun ini karena eklamsia/ preeklamsia (HDK) 2 (40\%), kemudian pendarahan $2(40 \%)$ dan emboli 1 (20\%). untuk data hiv dan aids pada tahun 2015 di Kabupaten Lombok Barat sebanyak 6 kasus HIV dan 1 kasus baru AIDS. Maka secara kumulatif di laporkan sampai saat ini di Kabupaten Lombok Barat terdapat 67 orang kasus HIV dan 79 kasus aids. Sedangkan menurut pencatatan tahun 2015 tidak ada kematian karena AIDS.

Kabupaten Lombok Barat merupakan satusatunya Kabupaten yang masuk verifikasi APE tahun 2016 ini. Menurut INiken Kiswandari jelas wanita yang telah mendedikasikan dirinya selama 30 tahun pada bidang ini.Selaku Ketua Tim Verifikasi Evaluasi mengatakan tahun ini dinilai semangat untuk memperjuangkan perempuan dan perlindungan anak sedikit menurun disbanding tahun-tahun sebelumnya."Tahun ini hanya diikuti oleh 17 Provinsi saja," ujar nya. Melalui penilaian APE ini kedepannya Pemerintah Daerah akan lebih memperhatikan lagi program pembangunan kaitannya dengan pemberdayaan dan perlindungan anak. "Kurangnya perempuan dalam program pembangunan serta kualitas yang rendah akan berdampak pada pembangunan bangsa ini. Jumlah perempuan jumlahnya hampir setengah penduduk dunia $34 \%$ nya adalah anak-anak".

Berdasarkan latar belakang hal tersebut penulis tertarik untuk melakukan penelitian dengan judul "Analisis Proses Formulasi Peraturan Daerah (Studi Pada Peran DPRD Lombok Barat dalam Proses Formulasi Perda No 3 Tahun 2015 tentang Pedoman Umum Pelaksanaan Pengarusutamaan Gender dalam Pembangunan di Kabupaten Lombok Barat)". 


\section{Tinjauan Pustaka}

\section{Kebijakan Publik}

Udoji seperti dikutip oleh Abdul Wahab (2012:15) mendefinisikan kebijakan publik sebagai "an sanctioned course of actions addressed to a particular problem or group of related problem that affect society at large" (suatu tindakan bersanksi yang mengarah pada suatu tujuan tertentu yang diarahkan pada suatu masalah atau sekelompok masalah tertentu yang saling berkaitan yang mempengaruhi sebagian besar warga masyarakat). Selanjutnya, menurut Anderson sebagaimana dikutip oleh Winarno (2002:5) menyebutkan bahwa kebijakan publik "purposive course of actions or inactions undertaken by an actors or set of actors in dealing with a problem or matter of concern" (merupakan arah langkah tindakan yang mempunyai maksud yang ditetapkan seseorang atau sejumlah aktor dalam menangani suatu masalah atau persoalan).

\section{Proses Formulasi Kebijakan}

Menurut Anderson dalam (Winarno 2007:93) formulasi kebijakan menyangkut upaya menjawab pertanyaan bagaimana berbagai arternatif disepakati untuk masalah-masalah yang dikembangkan dan siapa yang berpartisipasi.

Formulasi kebijakan sebagai suatu proses menurut Winarno (1989:53), dapat dipandang dalam 2 (dua) macam kegiatan. Kegiatan pertama adalah memutuskan secara umum apa yang apa yang harus dilakukan atau dengan kata lain perumusan diarahkan untuk memperoleh kesepakatan tentang suatu alternatif kebijakan yang dipilih, suatu keputusan yang menyetujui adalah hasil dari proses seluruhnya. Sedangkan kegiatan selanjutnya diarahkan pada bagaimana keputusan-keputusan kebijakan dibuat, dalam hal ini suatu keputusan kebijakan mencakup tindakan oleh seseorang pejabat atau lembaga resmi untuk menyetujui, mengubah atau menolak suatu alternatif kebijakan yang dipilih. Sejalan dengan pendapat Winarno, maka Islamy (1991:77) membagi proses formulasi kebijakan kedalam tahap perumusan masalah kebijakan, penyusunan agenda pemerintah, perumusan usulan kebijakan, pengesahan kebijakan, pelaksanaan kebijakan dan penilaian kebijakan.

\section{Model-Model Formulasi Kebijakan}

Memahami formulasi kebijakan publik berarti juga kita perlu mengetahui model-model perumusan kebijakan publik yang telah banyak digunakan selama ini oleh

Negara/lembaga/institusi dalam penetapan keputusannya.Menurut Thomas R. Dye dalam bukunya Undesrstanding Publik Policy (1995) setidaknya terdapat Enam model formulasi kebijakan yaitu: Model Institusional, Model Elitmassa, Model Kelompok, Model Sistem-Politik, Model Rational-Comprehensive, dan Model Inkremental.

\section{Proses dan Tahap-Tahap Dalam Perumusan Kebijakan Publik}

Kebijakan publik adalah aturan tertulis yang merupakan keputusan formal organisasi, yang bersifat mengikat, yang mengatur prilaku dengan tujuan untuk menciptakan tata nilai baru dalam masyarakat. Jones (1996) mengemukakan tahapan-tahapan dalam perumusan kebijakan publik, yaitu: Perception/definition, Aggregation, Organization, Representation, Agenda Setting, Formulation, Legitimation.

\section{Aktor dalam Formulasi Kebijakan}

Sesuai pendapat Lester dan Steward dalam Kusumanegara (2010:88-89), para aktor perumus kebijakan terdiri dari:

a) Agen pemerintah: yaitu terdiri dari para birokrat karier. Mereka adalah aktor yang mengembangkan sebagian besar usulan kebijakan (inisiator kebijakan).

b) Kantor kepresiden; yaitu presiden atau aparat eksekutif. Keterlibatan presiden dan perumusan kebijakan ditunjukan dengan pembentukan komisi kepresidenan, task forces dan komite antar organisasi:

c) Konggres(lembaga legislatif): lembaga ini berperan dalam melegislasi kebijakan baru maupun merevisi kebijakan yang dianggap keliru. Di negara-negara demokrasi, peran legislatif dalam perumusan kebijakan didasarkan pada keberadaan mekanisme check and balances dengan pihak eksekutiff.

d) Kelompok kepentingan: di Negara demokrasi, kelompok kepentingan merupakan aktor yang terlibat dalam perumusan kebijakan spesifik.

Pelaku perumusan kebijakan publik pada dasarnya dapat dibagi dalam dua kelompok, yaitu:

1. Resmi, yang termasuk dalam pelaku ini adalah lembaga pemerintah seperti: Birokrasi, Presiden (Eksekutif), DPR/D (Legislatif) dan Mahkamah Agung beserta badan peradilan di bawahnya (Yudikatif).

2. Tidak resmi, yang termasuk dalam pelaku ini adalah Kelompok Kepentingan, Partai Politik, LSM, Media Massa dan Manajemen Individu 


\section{Dewan Pewakilan Rakyat Daerah (DPRD)}

Dewan Pewakilan Rakyat Daerah (DPRD) merupakan lembaga Perwakilan Rakyat Daerah yang berkedudukan sebagai unsur lembaga Pemerintahan Daerah. Sebagai unsur pemerintahan daerah, DPRD memiliki tanggung jawab yang sama dengan pemerintahan daerah dalam rangka menjalankan roda pemerintahan daerah. DPRD adalah mitra kerja dan memiliki kedudukan yang sejajar dengan Pemerintahan Daerah. Dalam kedudukan tersebut, DPRD di lengkapi dengan beberapa fungsi, yaitu:

1. Legislasi yaitu fungsi membentuk peraturan daerah yang dilakukan bersama kepala daerah.

2. Anggaran yaitu bersama kepala daerah menyusun dan menetapakan Anggaran Pendapantan dan Belanja (APBD) setiap tahun.

3. Pengawasan yaitu melaksanakan pengawasan terhadap pelaksanaan Undang-Undang, Peraturan Daerah Dan Peraturan Kepala Daerah.

\section{Prosedur Penyusunan PERDA}

Penyusunan dan kepada pengajuan rancangan Perda menurut Undang-Undang adalah Haknya Kepala Daerah. Artinya, Rancangan Perda diajukan oleh Kepala Daerah kepada DPRD dan dibahas bersama-sama antara DPRD dan Kepala daerah untuk mendapatkan persetujuan bersama.

Penyusunan Rancangan Perda adalah sangat menentukan bagi kelancaran pembahasan di DPRD. Karena itu, kualitas suatu Perda dan pengambilan keputusan atas Rancangan Perda menjadi Perda sangat ditentukan oleh bagaimana dan dengan cara bagaimana Perda itu disusun. Setidaknya suatu Rancangan Perda harus didahului dengan menyusun naskah akademik. Dengan didahului atau disertai dengan naskah akademik, maka ia sangat memudahkan bagi pembahasan Rancangan Perda untuk ditetapkan menjadi Perda, maka tahaptahapan pembahasan Perda akan lebih mendalam dan setiap tahap pembahasan yang harus dilalui dapat berjalan dengan baik.

\section{Metode Penelitian}

Jenis penelitian yang dipergunakan adalah penelitian deskriptif dengan pendekatan kualitatif. Narasumber dalam penelitian ini yaitu pihak-pihah yang terkait dan terlibat dalam proses Formulasi Perda No 3 tahun 2015. Hal ini akan merujuk pada lokasi penelitian yaitu orang-orang atau pejabat terkait yang melaksanakan tugas dan fungsi terkait formulasi atau pembuatan Perda No. 3 tahun 2015.
Teknik penelitian yang digunakan dibedakan menjadi tiga, yaitu: 1. Wawancara, 2. Observasi 3. Dokumentasi.

\section{Hasil dan Pembahasan}

1. Analisis Proses Formulasi Peraturan Daerah (Studi Pada Peran DPRD Lombok Barat dalam Proses Formulasi Perda No 3 Tahun 2015 tentang Pedoman Umum Pelaksanaan Pengarusutamaan Gender dalam Pembangunan di Kabupaten Lombok Barat).

Anderson dalam Winarno (2007:93) formulasi kebijakan menyangkut upaya menjawab pertanyaan bagaimana berbagai alternatif disepakati untuk masalah-masalah yang dikembangkan dan siapa yang berpartisipasi. Dalam studi ini, alasan ketertinggalan perempuan daripada laki-laki, yang mana dihampir semua lini kehidupan (pendidikan, kesehatan, perekonomian, politik dan lain sebagainya. Hal ini membuat DPRD Kabupaten Lombok Barat berinisiatif dalam Formulasi Kebijakan bidang gender ini. Hal ini juga mengarah pada model formulasi kebijakan institusional.

Ini menandakan bahwa DPRD Kabupaten Lombok Barat di bagian Komisi IV memiliki perhatian khusus dan serius terkait isu yang mereka aspirasikan dan inisiasikan. Alasan terkait mengusul PUG ini karena banyak terlihat fenomena-fenomena sosial yang terjadi di masyarakat khususnya bagi perempuan yang kurang di perhatikan hak-haknya dan selalu di remehkan dalam dunia kerja. Sehingga komisi IV menjadikan PUG sebagai RAPERDA supaya dapat menjamin hak yang sama antara perempuan dan laki-laki untuk menikmati hak-hak warga Negara di bidang ekonomi, sosial budaya, politik, dan hukum sebagai upaya mewujudkan kesetaraan dan keadilan gender dalam pembangunan. Maka DPRD Kabupaten Lombok Barat melakukan langkah-langkah untuk mengidentifikasikan isu terkait pengusulan dari Badan Keluarga Berencana Dan Pemberdayaan Perempuan (BKBPP). Adapun dalam penyusunan RAPERDA tentang Pengarusutamaan Gender (PUG) ini memiliki beberapa tahap untuk mengidentifikasi fenomena-fenomena yang terjadi di lapangan terkait penyusunan RAPERDA tentang Pengarusutamaan Gender dan beberapa langkah-langkah yang harus di lakukan sebagai berikut:

1. Langkah 1 : Identifikasi isu dan masalah

DPRD Kabupaten Lombok Barat selaku perancang Perda perlu membuat Perda atas nama dan untuk kepentingan masyarakat. Langkah pertama yang harus diambil adalah mengajukan pertanyaan mengenai jenis permasalahan yang dihadapi oleh masyarakat. 
Permasalahan dapat mencakup banyak hal,antara lain degradasi dan deviasi sumber daya, konflik pemanfaatan antar pihak yang mengakibatkan keresahan sosial, dan lain-lain. Selain mengidentifikasi masalah, RAPERDA harus pula mengidentifikasi penyebab terjadinya masalah (akar masalah) dan pihakpihakyang terkena dampak dari berbagai masalah tersebut.

2. Langkah 2 : Identifikasi Landasan Hukum, dan Bagaimana PERDA Baru dapat Memecahkan Masalah Identifikasi legal baseline juga penting karena meliputi analisis terhadap pelaksanaan dan penegakan hukum dari peraturan perundang-undangan yang ada. Melalui analisis ini, dapat diketahui bagianbagian dari Perda yang ada, yang telah dan belum/tidak ditegakkan, termasuk yang mendapat pendanaan dalam pelaksanaannya berikut alasan yang menyertai, dan instansi yang bertanggung jawab atas pelaksanaan tersebut.

3. Langkah 3: Penyusunan Naskah Akademik Dalam penyusuan Naska Akademik DPRD Kabupaten Lombok Barat bahwa selesai Naska Akademik di setujui oleh Badan Legislasi dan dibawah ke Rapat Paripurna dan DPRD Kabupaten Lombok Barat mengundang tim ahli (sementara) dari Universitas Mataram dengan konsen terhadap pemberdayaan ini dengan naska akademiknya professor dari Universitas Mataram dan melakukan Publik Hearing untuk mendengar masukan dari masyarakat.

Dalam Pasal 1 angka 7 Peraturan Presiden Republik Indonesia Nomor 68 Tahun 2005 tentang Tata Cara Mempersiapkan Rancangan Undang-Undang, Rancangan Peraturan Pemerintah Pengganti Undang-Undang, Rancangan Peraturan Pemerintah dan Rancangan Peraturan Presiden dinyatakan bahwa Naskah Akademik adalah naskah yang dapat dipertanggungjawabkan secara ilmiah mengenai konsepsi yang berisi latar belakang, tujuan penyusunan, sasaran yang ingin diwujudkan dan lingkup, jangkauan, objek atau arah pengaturan Rancangan Undang-Undang. Dalam ketentuan Pasal 5 ayat (1) Peraturan Presiden tersebut dinyatakan bahwa "Pemrakarsa dalam menyusun Rancangan Undang-undang dapat terlebih dahulu menyusun Naskah Akademik mengenai materi yang akan diatur dalam Rancangan UndangUndang." Kata "dapat" berarti tidak merupakan keharusan. Sejalan dengan ketentuan Pasal 5 ayat (1) tersebut maka untuk penyusunan Peraturan Daerah untuk substansi tertentu dapat juga terlebih dahulu dibuatkan Naskah Akademik. Selanjutnya dalam ketentuan Pasal 5 ayat (3) Peraturan Presiden tersebut dinyatakan bahwa "Naskah Akademik paling sedikit memuat dasar filosofis, sosiologis, yuridis, pokok dan lingkup materi yang akan diatur".

Dari aspek proses penyusunan peraturan perundang-undangan, penelitian hukum adalah merupakan langkah awal/persiapan pada tahap pra legislasi. Hasil penelitian merupakan bahan dasar untuk menunjang tindak lanjutnya, yaitu penyusunan naskah akademik atau naskah rancangan peraturan perundang-undangan.

4. Langkah 4: Penulisan Rancangan Perda

Pekerjaan menyusun peraturan daerah seperti halnya, kodifikasi hukum, dan rancangan peraturan perundang-undangan memiliki spesifikasi tertentu. Himpunan peraturan perundang-undangan disusun berdasarkan derajat peraturan dan waktu penetapannya. Sedangkan kodifikasi hukum disusun secara sistematis menurut rumpun masalah dan dikelompokkan secara sistematis dalam Buku, Bab, Bagian, Paragraf, dan Pasal-Pasal.

5. Langkah 5 : Penyelenggaraan Konsultasi Publik

Bahwa Interaksi dengan masyarakat merupakan upaya yang lentur, dan harus diintegrasikan ke dalam proses penulisan rancangan Perda karena masukan dari lembaga yang terkait dengan pengarusutamaan gender ini sehingga Dewan Perwakilan Rakyat Daerah melakukan Publik Hearing. Proses konsultasi dan penulisan bersifat interaktif, saling mengisi dan mempengaruhi. Berdasarkan ketentuan dalam Pasal 28 (Rancangan) Peraturan Presiden tentang Tata Cara Mempersiapkan Rancangan Peraturan Daerah sebagai pelaksanaan Pasal 27 Undang-Undang Nomor 10 Tahun 2004 tentang Pembentukan Peraturan Perundangundangan dan Pasal 140ayat (3) UndangUndang Nomor 32 Tahun 2004 tentang Pemerintahan Daerah dinyatakan bahwa:

1. Masyarakat berhak memberikan masukan secara lisan atau tertulis sebagai bahan penyempurnaan dalam tahap penyiapan rancangan Perda.

2. Masyarakat dalam memberikan masukan harus menyebutkan identitas secara lengkap dan jelas. 
3. Masukan sebagaimana dimaksud pada ayat (1), memuat pokok-pokok materi yang diusulkan.

4. Masukan dari masyarakat sebagaimana dimaksud pada ayat (1), dapat diagendakan dalam rapat penyiapan rancangan Perda.

Mengidentifikasikan masalah itu penting dalam perumusan rancangan PERDA karena untuk mencari kebenaran terhadap masalah-masalah yang di usulkan oleh Badan Keluarga Berencana dan Pemberdayaan Perempuan (BKBPP). Sehingga DPRD Kabupaten Lombok Barat dan Pemerintah Daerah mulai menyusun RAPERDA terhadap usulan yang di sampaikan dan beberapa prosedur yang harus dilakukan sebagai berikut:

1. Proses Mendapatkan Persetujuan DPRD Kabupaten Lombok Barat.

Dalam proses mendapat persetujuan DPRD Kabupaten Lombok Barat melalui rapat paripurna untuk menyetujui rancangan peraturan daerah menjadi peraturan daerah dan menetapkan keputusaan DPRD Kabupaten Lombok Barat. Rapat paripurna Merupakan rapat anggota Dewan Perwakilan Rakyat Daerah yang dipimpin oleh ketua atau wakil Ketua Dewan Perwakilan Rakyat Daerah dan merupakan forum tertinggi dalam melakukan wewenang dan tugas kedewanan.

Adapun jadwal dalam pembahasan rapat draf RaPerda tentang Pengarusutamaan Gender bahwa:

1. Pengusul mengajukan draf RaPerda Inisiatif Dewan Perwakilan Rakyat Daerah kepada Pimpian Dewan Perwakilan Rakyat Daerah.

2. Dari rapat Pimpinan Dewan Perwakilan Rakyat Daerah menyampaikan hasil pembahasan draf RaPerda inisiatif Dewan Perwakilan Rakyat Daerah

3. Pandangan dari fraksi-fraksi Tentang Pengarusutamaan Gender

4. Jawaban pengusul atas pandangan fraksi-fraksi terhadap Pengarusutamaan Gender

5. Persetujuan, penetapan draf RaPerda usulan Inisiatif Dewan Perwakilan Rakyat Daerah

6. Penjelasan Banleg terhadap Draf RaPerda inisiatif Dewan Perwakilan Rakyat Daerah

7. Pandangan Kepala Daerah

8. Jawaban fraksi atas pandangan Kepala daerah

9. Dibentuk panitia khusus untuk mengkaji draf RaPerda inisiatif Dewan Perwakilan Rakyat Daerah

10. Laporan panitia khusus atas hasil pembahasanya dan persetujuan, penetapan draf RaPerda inisiatif Dewan Perwakilan Rakyat Daerah serta pendsapat Kepala Daerah.

Pembahasan RaPerda di DPRD baik atas inisiatif Pemerintah Daerah maupun atas inisiatif DPRD, dilakukan oleh DPRD bersama Bupati, Pemda membentuk Tim Asistensi dengan Sekretaris Daerah berada di Biro/Bagian Hukum. Tetapi biasanya pembahasan dilakukan melalui beberapa tingkatan pembicaraan. Tingkat-tingkat pembicaraan ini dilakukan dalam rapat paripurna, rapat komisi, rapat gabungan komisi, rapat panitia khusus dan diputuskan dalam rapat paripurna. Secara lebih detail mengenai pembahasan di DPRD baik atas inisiatif DPRD ditentukan oleh Peraturan Tata Tertib DPRD masing-masing. Khusus untuk RaPerda atas inisiatif DPRD, Kepala Daerah akan menunjuk Sekretaris Daerah atau pejabat unit kerja untuk mengkoordinasikan rancangan tersebut.

RaPerda inisiatif DPRD ini tentang Pengarusutamaan Gender ditetapkan menjadi Perda pada tanggal 24 juni 2015. Perda yang telah ditetapkan akan diserahkan kepada sekertaris daerah untuk diundangkan.

\section{Proses Pengesahan dan Pengundangan}

Apabila masih ada kesalahan teknik penyusunan Perda, Sekretaris Dewan Perwakilan Rakyat Daerahdengan persetujuan Pimpinan Dewan Perwakilan Rakyat Daerah dan Kepala Daerah dapat menyempurnakan teknik penyusunan RaPerda yang telah disetujui oleh Dewan Perwakilan Rakyat Daerah sebelum disampaikan kepada Kepala Daerah. Jika masih juga terdapat kesalahan teknik penyusunan setelah diserahkan kepada Kepala Daerah, Kepala Daerah dapat menyempurnakan teknik penyusunan tersebut dengan persetujuan Pimpinan Dewan Perwakilan Rakyat daerah. Setelah Perda diundangkan dan masih terdapat kesalahan teknik penyusunan, Sekretaris Daerah dengan persetujuan Pimpinan Dewan Perwakilan Rakyat Daerah dapat meralat kesalahan tersebut tanpa merubah substansi Perda melalui Lembaran Daerah. Pemda wajib menyebarluaskan Perda yang telah diundangkan dalam Lembaran Daerah agar semua masyarakat di daerah setempat dan pihak terkait mengetahuinya.

\section{Lembaran Daerah dan Berita Daerah}

Apabila RaPerda sudah ditetapkan menjadi Perda akan mempublikasikan Perda yang telah di sahkan. Supaya memberikan pelayanan 
kepada masyarakat bersifat transparan agar masyarakat Kabupaten Lombok Baratatau bahwa telah ada Perda tentang Pengarusutamaan Gender ini.

Berdasarkan Standar Operasional Prosedur (SOP) bawa Perda yang telah disahkan harus dipublikasikan. (1) Agar memiliki kekuatan hukum dan dapat mengikat masyarakat, Perda yang telah disahkan oleh Kepala Daerah harus diundangkan dalam Lembaran Daerah. (2) Untuk menjaga keserasian dan keterkaitan Perda dengan penjelasannya, penjelasan atas Perda tersebut dicatat dalam Tambahan Lembaran Daerah dan ditetapkan bersamaan dengan pengundangan Perda sebagaimana yang diundangkan di atas. Pejabat yang berwenang mengundangkan Perda tersebut adalah Sekretaris Daerah.

\section{Simpulan}

Peran DPRD dalam hal formulasi kebijakan Perda No. 3 Tahun 2015 Tentang Pedoman Umum Pelaksanaan Pengarusutamaan Gender Dalam Pembangunan dapat di lihat dari bagaimana DPRD Kabupaten Lombok Barat mengikuti prosedur penyusunanan Raperda dan penyiapan Raperda. Formulasi kebijakan itu dilakukan dengan langkahlangkah sebagai berikut: Identifikasi isu dan masalah, identifikasi landasan hukum dan bagaimana Perda baru dapat memecahkan masalah, penyusunan naskah akademik, penulisan rancangan perda, dan setelah dilakukan langkah-langkah tersebut maka Raperda di proses untuk mendapatkan persetujuan DPRD Kabupaten Lombok Barat melalui proses pengesahan dan pengundangan, lembaran daerah dan sampai berita daerah.

\section{Saran}

Adapun saran yang bisa diajukan adalah terkait dengan DPRD Kabupaten Lombok Barat hendaklah memperbaiki faktor penghambat dalam pembuatan rancangan Perda seperti belum adanya Sumber Daya Manusia (SDM) tetap yang memiliki kualitas lebih dan segera merekrut Tim Ahli untuk membantu pekerjaan dewan.

\section{Daftar Pustaka}

[1] Agustino, Leo, Dasar-Dasar Kebijakan Publik, Alfabeta, Bandung, 2008.

[2] Ansil, Cristine, Sistem Pemerintahan Indonesia, PT. Bumi Aksara, Jakarta, 2008.

[3] Astawa, Pantja, Hak Angket Dalam Sistem Ketatanegaraan Indonesia Menurut UndangUndang Dasar 1994, Disertasi Pascasarjana Unpad, Bandung, 2000.

[4] Dunn, W.N., Pengantar Analisis Kebijkan Publik Edisi kedua, Gajah Mada Unuversity Press, Yogyakarta, 2002.

[5] Rinusu, Pengarusutamaan Gender Dalam Pembangunan di Indonesia Teori dan Aplikasi, Kerjasama antara Kementerian Pemberdayaan Perempuan Republik Indonesia dan United National Development Program (UNDP), Jakarta, 2007.

[6] Sjafrisal, Teknik Praktis Penyusunan Pembangunan Daerah, Baduose Media, Jakarta, 2009.

[7] Suprihatini, Amin dan Suparyanto, Yudi. 2011. Mengenal Lembaga Negara Indonesia. Klaten:Saka Mitra Kompetensi.

[8] Sugiyono, Memahami Penelitian Kualitatif, Alfabeta, Bandung, 2005.

[9] Tjokrowinoto, Moeljarto, Pembangunan Dilema Dan Tantangan, Pustaka Pelajar, Yogyakarta, 2007.

[10] Wahab, Abdul, Analisis Kebijakan, PT. Bumi Aksara, Jakarta, 2012. 